acknowledgment of the remarkably effective and farsighted way in which he had used his position, from the beginning, to further psychiatric teaching and research.

Very great importance was attached by Mapother to this side of his work, and he felt strongly that it demanded the full time of one man, though it had been impossible for him to give it full time because of his administrative duties as superintendent, which were heavy. $\mathrm{He}$ fretted constantly at the restrictions which his other work imposed upon what he felt he ought to be doing in this regard, and more than a year ago he drew up a plan for the reorganization of the staff of the Hospital, which provided for the permanent separation, in different hands, of his two main functions. Owing to his tireless energy he accomplished much more, however, than he believed; and the influence of his teaching and of his guidance of the general lines of research was farreaching.

Mapother was himself first and foremost a clinician; and all his investigations were primarily clinical, for example, into alcoholic morbidity, the mental effects of head injury, and the neuroses of war. He understood very well, though, that research must be conducted along many lines, somatic, psychological and social, if knowledge in this conspicuously difficult and complex subject was to be advanced, and he sought constantly to synthesize neuro-physiology and psychology. He recognized two important needs : to bring into psychiatry first-class men, and to ensure that they should have a good training both in clinical psychiatry and in whatever scientific methods they were going to apply to psychiatric problems. He was aware that, in the past, fewer able men have been attracted towards psychiatry than towards other fields in medicine, and he thought that the best way to remedy this was to build up an outstanding university centre the achievements of which, especially in research, would influence the standards and reputation of psychiatry. Through the help of the Commonwealth Fund of America, and especially of the Rockefeller Foundation, he was able to carry this project a long way ; the London County Council showed a generous understanding of the value and importance of Mapother's efforts, which could not have been realized without its concurrence.

Mapother was a remarkably good judge of men, as was inevitable in so penetrating a clinical psychiatrist ; he saw through empty professions and slipshod efforts, but was eritically appreciative of good work. $\mathrm{He}$ therefore succeeded in gathering around him a group of able men who were glad to work under the conditions available at the Maudsley. He was determined that there should not be dilettante research in his hospital. He had seen the harm done by this, both in the more academic forms of research and in investigations into clinical problems, and he was careful, in the selection and training of his staff, to ensure that they should be thoroughly competent in the research methods employed. To his insistence on this must be largely attributed the high level of the research done under his stimulus and direction. $\mathrm{He}$ was happy to know, in the last few months of his life, that the War had not led to the disintegration of his staff, but that they were working, in the two hospitals to which they had removed, on those problems of psychiatry arising in war, to which he had himself paid so much attention.

\section{Mr. E. T. Cottingham}

SCrENCE, and more particularly the precision time measuring side, loses in the death of Mr. E. T. Cottingham one of the few outstanding men of Great Britain engaged in this research.

$\mathrm{He}$ was born at Ringstead, near Thrapston, and, although originally apprenticed to a tailor, his love for mechanical timepieces overcame his father's desires, eventually giving to Mr. Allen the task of teaching him to be a clockmaker in the village of Thrapston, where the whole of his life was spent.

Throughout, his interest has not been centred on one problem, for so varied were they that a few, such as church clocks, sewage pumping machinery, and fitting the surrounding blast furnaces with pyrometers, etc., occupied his attention. The proximity to Cambridge naturally gave him other problems which he so loved to solve. The advent of radio enrolled him as an early student and pupil and, I believe, he was one of the first to install his experimental set, dated October 1912. Wireless and time signals being inseparable, and from this to astronomical time-keeping, the care of the instruments at Greenwich in due course followed. He was also invited and accepted the invitation to accompany Sir Arthur Eddington in 1919 to Principe on the eclipse expedition. He will always be remembered for his simplification of the principles of Dr. Reifler's escapement, and the models he has left in the various observatories of the world stamp him as a genius in design and craftsmanship where simplicity is the keynote.

Frank Mercer.

\section{WE regret to announce the following deaths:}

M. Nicholas Arnold, honorary general administrator of the Belgian Colonies, who had a large share in the development of the Congo under Belgian auspices, especially from a horticultural and botanical aspoct.

Sir George Buchanan, K.C.I.E., consulting engineer especially concerning harbour, docks and river works, on April 14, aged seventy-four years.

The Right Hon. H. A. L. Fisher, O.M., F.R.S., warden of New College, Oxford, on April 18, aged seventy-five years.

Dr. A. C. Haddon, F.R.S., emeritus reader in ethnology in the University of Cambridge, on April 20 , aged eighty-four years.

Prof. Heinrich Preiswerk, visiting professor of mineralogy in the University of Basle, aged sixtyfour years.

Prof. W. R. Scott, F.B.A., Adam Smith professor of political economy in the University of Glasgow, on April 3, aged seventy-one years. 